
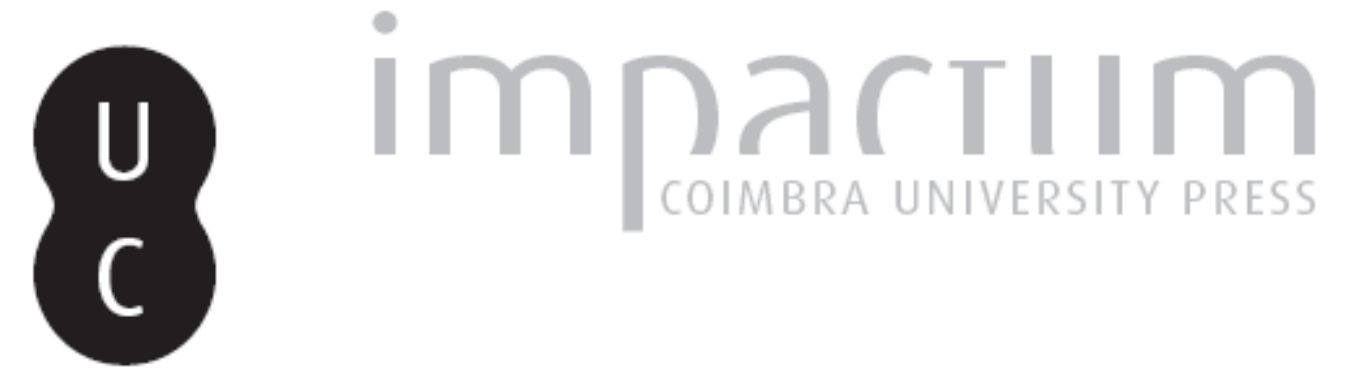

\title{
Mithras at Pax lulia: a re-examination
}

Autor(es): $\quad$ Edmondson, J. C.

Publicado por: Imprensa da Universidade de Coimbra

URL persistente:

URI:http://hdl.handle.net/10316.2/45675

DOI:

DOI:https://dx.doi.org/10.14195/1647-8657_23_5

Accessed : $\quad$ 26-Apr-2023 03:30:48

A navegação consulta e descarregamento dos títulos inseridos nas Bibliotecas Digitais UC Digitalis, UC Pombalina e UC Impactum, pressupõem a aceitação plena e sem reservas dos Termos e Condições de Uso destas Bibliotecas Digitais, disponíveis em https://digitalis.uc.pt/pt-pt/termos.

Conforme exposto nos referidos Termos e Condições de Uso, o descarregamento de títulos de acesso restrito requer uma licença válida de autorização devendo o utilizador aceder ao(s) documento(s) a partir de um endereço de IP da instituição detentora da supramencionada licença.

Ao utilizador é apenas permitido o descarregamento para uso pessoal, pelo que o emprego do(s) título(s) descarregado(s) para outro fim, designadamente comercial, carece de autorização do respetivo autor ou editor da obra.

Na medida em que todas as obras da UC Digitalis se encontram protegidas pelo Código do Direito de Autor e Direitos Conexos e demais legislação aplicável, toda a cópia, parcial ou total, deste documento, nos casos em que é legalmente admitida, deverá conter ou fazer-se acompanhar por este aviso.

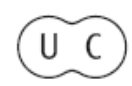


FACULDADE DE LETRAS

INSTITUTO DE ARQUEOLOGIA

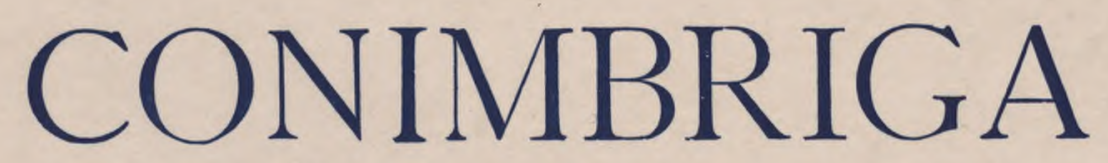

VOLUMEXXIII

UNIVERSIDADE DE COIMBRA

1984 
J. C. EDMONDSON

M. A., Christ's College, Cambridge

MITHRAS AT PAX IULIA - A RE-EXAMINATION

Conimbriga, XXIII (1984), p. 69-86

SUMMARY: Some new suggestions for a reading of the text of the supposedly Mithraic inscription (CIMRM 801 bis) from Pax Iulia (Lusitania) are made. A full discussion of the text and its wider implications raises important doubts as to whether the inscription can be used as evidence for a regular cult of Mithras.

RESUmo: Dão-se novas sugestões de leitura do texto da suposta inscrição mitraica (CIMRM 801 bis) de Pax Iulia (Lusitânia). Uma discussão cabal do texto e das suas mais vastas implicações levanta sérias dúvidas em relação à sua utilização como documento dum regular culto de Mitra. 
(Página deixada propositadamente em branco) 


\section{MITHRAS AT PAX IULIA - A RE-EXAMINATION}

\section{INTRODUCTION}

Discussions of the cult of Mithras in Lusitania have centred upon the rich haul of inscriptions and cult statues from the provincial capital, Augusta Emerita 0). As elsewhere, a connexion can be made between the cult and the presence of Roman soldiers: a frumentarius of the Legio VII Gemina can be seen to have dedicated an altar to Mithras in A.D. $155{ }^{(2)}$. In addition, attention has also been drawn to evidence from elsewhere in the province - from Olisipo $\left({ }^{3}\right)$, Caparra $\left({ }^{4}\right)$, Tróia $\left(^{5}\right)$ and Pax Iulia $\left.{ }^{(}\right)$.

Pax Iulia (modern Beja) was a Roman colony and the juridical centre of the conventus Pacensis $\left({ }^{7}\right)$. It occupied an important

$\left.\mathbf{I}^{1}\right)$ See, for example, P. Paris, Les restes du culte de Mithra en Espagne et $k$ Mithraeum de Mérida, «Revue archéologique», 24, 1914, 1-31; J. LeIte DE VAsconcelos, Religiões da Lusitânia, Lisbon, III, 1913, 334-341; CIMRM $772-797$.

(2) CIMRM 793. For soldiers and Mithras, in general, see G. M. DANiELs, The role of the Roman army in the spread and practice of Mithraism, in J. R. Hinne ls (ed.), Mithraic Studies, Manchester, II, 1975, 249-274.

(3) CIL II 258, $259=$ CIMRM 799, 800. J. DE Alarcão, Portugal romano, Lisbon, 1974, 172-3 casts doubt on the Mithraic significance of these inscriptions.

(4) CIMRM 801.

(5) CIMRM 798 and figure 217.

$\left.{ }^{6}\right)$ For full bibliography, see p. 3-4. A good example of the general inteipretation of the inscription is provided by ALARCÃ O, op. cit.y (note 3), 173.

(7) Pliny $\mathrm{NH}$ 4.22.117.

Conimbriga, 23 (1984), 69-86 
geographical position controlling the extensive plateau of the Lower Alentejo. Little now survives in the way of Roman monuments in the town, but its territory has revealed a relatively high number of romanized villa sites $\left(^{8}\right)$.

The only evidence, to my knowledge, for a cult of Mithras at Pax Iulia consists of just one inscription. It was first published in 1944 and has been discussed by various scholars, none of whom has satisfactorily solved the various problems of the exact reading of the text. Given its importance for discussions of the cult of Mithras in the Iberian peninsula, a re-examination of the text and its implications is now necessary.

\section{TEXT}

Plaque of ashen-grey marble (probably from quarries at Trigaches, to the north-west of Beja), with moulding of two parallel grooves. Broken at top-left and, to lesser extent, at bottom-right corners. Surface much abraded in parts. Displayed in Museu Regional de Beja, inventory number B-36. Exact provenance given with no more precision than 'area around Beja ${ }^{5}$.

Dimensions: $0.29 \mathrm{~m}$ high, $0.31 \mathrm{~m}$ wide, $0.08 \mathrm{~m}$ thick.

Height of letters: $0.025 \mathrm{~m}$ (line 1), $0.025 \mathrm{~m}-0.02 \mathrm{~m}$ (line 2), $0.015 \mathrm{~m}$ (lines $3-7$ ).

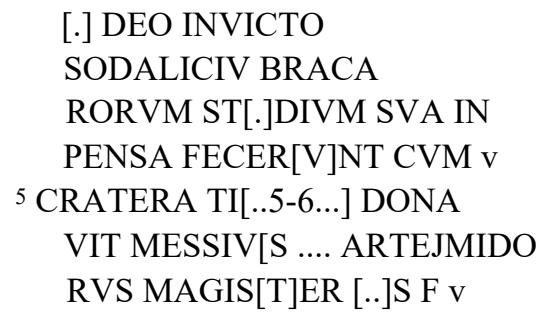

$\left.{ }^{8}\right)$ On the town, see A. VIana, Origem e evolução histórica de Beja, Beja, 1943. On general economic conditions of the area, J. DE ALARCão, Sohre a economia rural do Alentejo na época romana, "Conimbriga», 15, 1976, 5-44. On villas, J.-G. Gorges, Les villas hispano-romaines: inventaire et problématique archéologiques ${ }_{i}$ Paris, 1979, 471-77.

Conimbriga, 23 (1984), 69-86 
Expansion: [S(oli) or «j»] Deo Invicto / sodaliciu(m) Braca/rorum $\mathrm{st}[\mathrm{u}]$ dium sua in/pensa fecer[u]nt cum $i$ ? / cratera ti[tulum] dona/vit Messiu[s M(arci) ? 1(ibertus) ? Arte] mido/rus magis[t]er [d(e)] s(uo) f(ecit) or s(uo) p(osuit) or s(ua) p(ecunia) .

Date: On palaeographical grounds, second half of the second century A. D. The lack of any confirming factors makes this suggestion somewhat tentative.

Apparatus criticus

\begin{tabular}{|c|c|c|}
\hline \multirow{6}{*}{$\begin{array}{l}\text { line } 2 \\
\text { line } 3\end{array}$} & BRAGA & Viana 1958 \\
\hline & S(e)DIVM & Viana 1944, $1948=$ Bellido 1948 \\
\hline & SEDIVM & ILER \\
\hline & SELDIVM & Lambrino $=A E \backslash C I M R M$ \\
\hline & SPODIYM & Viana $1955,1958,1961-2$ \\
\hline & $\mathrm{S}[\mathrm{PON}] \mathrm{DIVM}$ & Bellido $1967=$ \\
\hline \multirow[t]{2}{*}{ line 4} & OVM & Viana $1944,1948=$ Bellido 1948 \\
\hline & OVMT (or CVMT) & Lambrino \\
\hline \multirow[t]{5}{*}{ line 5} & CRATE(r?) AT(f?) & Viana 1944, $1948=$ Bellido 1948 \\
\hline & T. F. $[\ldots \ldots \ldots . .]$. & Viana 1958 \\
\hline & T. F[1(avius Aper?)] & Lambrino \\
\hline & T. F[lavius] & $A E \backslash C I M R M$ \\
\hline & $\mathrm{T}[\mathrm{RIPODEM}]$ & Bellido $1967=$ \\
\hline
\end{tabular}

\section{Bibliography}

1. A. Viana, Museu regional de Beja: secção lapidar, «Arquivo de Beja», 1, 1944, p. 357, no. 8.

2. A. García y Bellido, El culto de Mithras en la peninsula ibérica, «BRAH», 122, 1948, p. 302, no. 5.

3. A. Viana, Inscrição mitraica de Beja, "Arquivo de Beja», 5, 1948, p. 195.

4. A. R. Da Cunha, Novíssimas inscrições romanas de Braga, «Bracara Augusta», 4, 1952, p. 244-245. 
5. S. LAmb Riño, Les divinités orientales en Lusitanie et le sanetuaire de Panóias, «Bulletin des études portugaises», 17, 1953, p. 98-100.

6. $A E 1956$, no. 254.

7. A. Viana, Notas históricas, arqueológicas e etnográficas do Baixo Alentejo, «Arquivo de Beja», 12, 1955, p. 20-22.

8. A. Viana, Lápide Bejense, consagrada a Juno, «Actas e Memórias do I Congresso Nacional de Arqueologia, Lisboa, 1958», II, Lisbon, 1970, p. 111.

9. M. J. Vermaseren, Corpus inscriptionum et monumentorum religionis Mithriacae, II, The Hague, 1960, p. 35, no. 801bis.

10. A. Viana, Notas várias, «Arquivo de Beja», 18-19, 1961-1962, p. 116-117.

11. A. Garcia y Bellido, Les religions orientales dans VEspagne romaine (= Etudes préliminaires aux réligions orientales dans Vempire romain, 5), Leiden, 1967, p. 34-35, no. 15.

12. HAEp, no. 2695.

13. ILER no. $281=$ no. 282 .

\section{Bibliographical note}

The discussions of Viana 1944, Bellido 1948 and Viana 1948 are all based on the text established by Viana 1944. $A E$ 1956, 254 reproduces the text of Lambrino. HAEp 2695 reproduces the text of Bellido 1967. ILER 281 and 282 duplicate the inscription, led astray by the inadequate text of da Cunha.

\section{COMMENTARY}

a) Line 1

Some editors have been keen to supply an initial ${ }^{\prime} \mathrm{M}^{5}$ before 'Deo Invicto $^{5}$ to strengthen the case that the inscription is concerned with the cult of Mithras. Garcia y Bellido admits that this is a mere supposition which rests on the supposed presence 
of two traces of the lower part of an ${ }^{\prime} \mathrm{M}^{5}{ }^{(9)}$. This hypothesis seems doubtful: the marks on the stone do not accord with the supposed presence of an 'M $\backslash$ Moreover, the normal dedicatory formula for Mithras was not 'Mithrae Deo Invicto's, but rather 'Deo Invicto Mithrae ${ }^{*}\left(10^{*}\right)$. The reading of an ' $\mathrm{S}^{5}$ would, in my view, be a more plausible hypothesis, giving the invocation 'Soli Deo Invicto ${ }^{5}$, attested at Brixia and Aquileia (n). Alternatively, the inscription may have begun with a hedera, thus leaving the simple invocation 'Deo Invicto', attested, for example, at Augusta Emerita (12). On balance, the generally neat arrangement of the left-hand margin makes the latter view less likely.

The epithet 'invictus' 5 is not only applied to Mithras and Sol; examples can be found of its attribution to Hercules, Mars, Mercury, Serapis, Silvanus and Isis, as well as local deities such as Aulisva from Mauretania (13).

The small't $t^{5}$ of 'invicto ${ }^{5}$ should perhaps be seen as a stylistic device rather than as an insertion of an earlier omitted letter $\left(14^{*}\right)$.

\section{b) Sodaliciu Bracarorum (lines 2-3)}

A sodalicium was another term for a collegium, as a text of the Digest makes explicitly clear $\left({ }^{15}\right)$. At Pax Iulia this sodalicium comprised a group of immigrant settlers from Bracara Augusta (modern Braga), the juridical centre of the conventus Bracaraugustanus in the province of Hispania Tarraconensis $\left({ }^{16}\right)$. It is

(9) BELLIDO 1967, 34.

(10) CIL VI $734=$ CIMRM 517 (Rome): deo invicto Mithrae; CIMRM 781 (Emerita): invicto deo Mithrae.

(U) CIMRM 713 (Brixia); CIMRM 752 (Aquileia).

(12) CIMRM 794, 795, 796.

$\left(1^{3}\right)$ For example, Hercules: ILS 3407, 3408, 3409, 4536; Mars: ILS 8935; Mercury: ILS 3197, 5187; Serapis: ILS 4380; Silvanus: ILS 3562; Isis: ILS 4375; Aulisva: ILS 4492.

(u) It can be paralleled in an inscription from Emerita: CIL II 470; for photograph, see Augusta Emerita: actas del bimilenario de Mérida, Madrid, 1976, plate L.

(15) Dig. 47. 22.1.

(16) Pliny $N H$ 3.3.18; 3.3.28. On Bracara in general, see A. Tranoy, La Galice romaine, Paris, 1981, 193-96 (with plan of town). 
impossible to prove the reason for their settling in Pax Iulia, but the importance of mining in the areas around both towns may provide some clue $\left({ }^{17}\right)$. Migration is also attested in the reverse direction (18). The formation of collegiate groups of immigrant settlers (peregrini) is found elsewhere, for example at Forum Hadriani (Germania Inferior) (19) and Marbach (Germania Superior) $\left({ }^{20}\right)$.

More interestingly, the use of the term 'sodalicium* can be paralleled from an inscription found in the vicinity of Braga itself. It is also a plaque (and probably, therefore, to be set into the wall of a building), recording a sodalicium urbanorum $\left({ }^{21}\right)$.

There are also parallels from the Iberian peninsula for the omission of the final'm* of an '-urn* ending. It is commonly found in the designation of local clan names in the north of Lusitania, which may suggest that the feature was a survival from indigenous linguistic practices $\left({ }^{22}\right)$. It occurs frequently in inscriptions of the Republican period in general and survives into the Empire $\left({ }^{23}\right)$. In the Iberian peninsula the feature does not seem to be common in any particular period, thus ruling it out as a dating criterion.

The fact that the dedication is made by a sodalicium is crucial for the discussion of this inscription as evidence for a cult of Mithras at $\operatorname{Pax}$ Iulia. It was the view of Cumont $\left({ }^{24}\right)$, followed

$\left({ }^{17}\right)$ See D. F. de Almeida, Mineração romana em Portugal, «La Minería Hispana e Ibero-americana», 1970, I, 195-220.

(18) CIL II 2425.

(19) J.-P. Waltzing, Étude historique sur les corporations professionales chez les romains depuis les origines jusqu'á la chute de VEmpire d'Occident, Louvain, 1895-1900, III, 582, no. 2139.

(20) Ibid., Ill, 589, no. $2164=$ CIL XIII 6453.

(21) CIL II 2428.

(22) General examples from the Iberian peninsula: monumentu (CIL II 6297 \& 6298), praemiu (CIL II 2265), tumulu (CIL II 5729); for clan names see M. L. Al в E r tos Firmat, Organizaciones suprafamiliares en la Hispania antigua (= Studia archaeologica, 37), Valladolid, 1975, esp. 22-23 and list, p. 19.

(23) Republican examples: ILLRP 332, 713, 1073, 1147. Example from reign of Vespasian: ILS 986; from reign of Domitian: ILS 3546.

${ }^{24}$ F. Cumont, Textes et monuments figurés relatifs aux mystères de Mithra, Paris, I, 1896, 326-7.

Conimbriga, 23 (1984), 69-86 
and elaborated by Wiist, $\left({ }^{25}\right)$, that sodalicium was the title adopted by Mithraic communities in general. This hypothesis, however, was based on a small number of untypical inscriptions and so cannot be held with any certainty. I can only trace two other instances (both from Rome) where the term is used in connexion with a formal collegiate organization for the worship of Mithras $\left({ }^{26}\right)$. Moreover, the general rarity of Mithraic album inscriptions - in stark contrast to other religious groups - makes one wonder if Mithraic groups were ever regularly organized as collegia. Indeed this inscription would provide the only example of a collegiate structure for the cult of Mithras in the Iberian peninsula $\left({ }^{27}\right)$. Such factors raise important doubts over its Mithraic significance.

\section{c) Line 3}

A major problem in the restoration of the text occurs over the second word in the line. Definitely visible on the stone are the initial letter 's' and the final four letters 'dium 5 . The gap in the middle of the line has led to a barrage of suggestions, none satisfactory. Of these, the arguments of Bellido in favour of 'spondium 5 (tying in with the later mention of a cratera) are enticing, but have to be rejected $\left({ }^{28}\right)$. First, there is not sufficient space between the $\mathrm{V}$ and $\operatorname{the}^{\prime} \mathrm{d}^{5}$ to fit in the required letters for his reading, unless ligatures (not present elsewhere in the inscription) are to be postulated. It should also be noted that the stone-cutter favoured a wide girth for his 'o': note, for example, the $\mathrm{V}$ of deo (line 1) or sodaliciu (line 2). Secondly, and more importantly, it is questionable whether'fecerunt ${ }^{5}$ is the most appropriate word to use with 'spondium', a «vessel used in making libations» (29), unless we are to envisage the sodalicium hard at work with their tools.

(25) RE XV, columns 2142-2143.

H CIL VI $3728=C I M R M$ 361; CIL VI $717=C I M R M 519=$ $=I L S 4217$.

(27) BELLIDO 1967, 34.

$\mathrm{H}$ Ibid.

(29) Lewis \& ShorT, A Latin Dictionary, s.v. spondeum. 
Vermaseren's seldium would fit the available space, but its meaning remains hopelessly obscure, as he himself acknowledges $\left({ }^{30}\right)$.

A closer examination of the stone reveals traces of the second letter: the upper half of an upright, joined at the top by the left part of a horizontal. I would, therefore, propose the reading of $a^{\prime} t^{5}$ here. The width of the horizontal is consistent with the other ' $\mathrm{t}^{5} \mathrm{~s}$ on the stone: for example, the't $\mathrm{t}^{5}$ of fecerunt (line 4) or cratera (line 5).

A consideration of the general purpose of the inscription helps to give an indication of the type of word that needs to be supplied. Since, first, the inscription is a plaque (note the thickness and the moulded surrounds) and, as such, designed to be set into the wall of a building and, secondly, the verb for which an object is required is fecerunt, I would suggest that the object has to be a building or part of a building or a fairly substantial artefact.

In the light of this, I would tentatively suggest reading 'studium 5 . It would meet the strict epigraphic requirements of the text and, as I hope to demonstrate, would fit with the general context of the inscription.

Both literary and epigraphic parallels, though scant, can be found for the use of the word 'studium' to designate a «place for study, study or school». Thus in the life of Marcus Aurelius we find ( $\left.{ }^{31}\right)$ :

philosophum (se egit) in omnibus studiis, templis, locis.

Similarly, an inscription from Rome records the building of a studium for Q. Pompeius Sosus and his wife Satriena Salvia $\left({ }^{32}\right)$ : dium

...morte obita ut monumentum haberemus fecimus vivi stu-

Note the use of the verb facere also in this text with studium.

(30) CIMRM 801 bis.

(31) SHA, M. Aurel. 26.

(32) CIL VI 33087 (lines 6-7 quoted). 
I would suggest that the studium was destined to be used as a central meeting-place for the sodalicium Bracarorum. Every collegium needed such a centre in which to hold its activities. As Waltzing demonstrated, the normal term for such a place was schola, but this did not exclude many other variant designations: for example, basilica, curia, domus, solarium, templum ( $\left.{ }^{33}\right)$. Studium can be taken as another variant, as yet unparalleled. The range of meaning of both studium and schola is strikingly similar: first, «the leisure given to learning, a learned conversation» (schola), «application to learning or studying, study» (studium); secondly, this abstract meaning is developed into a more concrete one: «place for learned conversation or instruction» (schola), «place for study, study, school» (studium) ( $\left.{ }^{34}\right)$; thirdly, both are used as synonymous terms for collegiate organizations: for example, the schola tubicinum from Brigetio (Pannonia Superior) or the schola fabrum at Apulum (Dacia) $\left.{ }^{35}\right)$, the studium Palladianum or the studium iuvenum cultorum dei Herculis at Beneventum ${ }^{(36)}$. Given this close semantic connexion, I would argue that studium is a plausible, if yet unparalleled, suggestion to denote the meeting-place of a collegium or sodalicium.

\section{d) Line 4}

The only problem in this line concerns the gap at the end, above which two letters appear in line 3. Of previous editors, only Lambrino faced this problem, in asking if a ' $t$ * could be read immediately after cum $\left({ }^{37}\right)$. This hypothesis cannot be supported after a close examination of the stone nor is the sense of the text then clear. It is my view that a small hedera can be made out beneath the first 'n' of inpensa (line 3).

(33) J.-P. Waltzing, op. cit(note 19), I, 211-231; texts: IV, 437-443.

(34) All meaning quoted from Lewis \& Sногт, op. cit., (note 29).

(35) CIL III 10997 (Brigetio); CIL III 1583 (Apulum); Waltzing, op. cit. (note 19), IV, 149 for other examples.

(36) ILS 6501, 7219; note also ILS 6502 (Beneventum).

( ${ }^{37}$ L A м в R INo, Bulletin des études portugaises, 1953. 


\section{e) Line 5}

The mention of a cratera here is not surprising, since such an item was essential for all collegia to be used not only in religious ritual, but also for the regular meals held in the meeting-place of such organizations $\left.{ }^{38}\right)$. There are many recorded dedications of such objects for collegiate use: for example, the splendid cratera argyrocorintha cum basi sua et hypobasi marmorea donated by L. Curtius Abascantus for the use of the corpus custodiariorum at Rome in A.D. $149{ }^{(39)}$. The dedication of a cratera in conjunction with a studium might at first seem a little eccentric; but if my arguments that a studium could have fulfilled the same function as a schola are convincing, then the need for a cratera is clear. Moreover, another inscription from Rome provides a good parallel: it records the dedication of a cratera as part of the accroutrements of a nymphaeum $\left({ }^{40}\right)$.

A cratera was certainly a common element in the ritual of the Mithraic cult and is often depicted in Mithraic iconography. Lusitania provides a clear example: a relief from Tróia shows Mithras in the usual guise of bull-slayer; in the lower part a servant lies on the ground next to a cratera, from which a serpent is winding its way up to drink, while a second servant is about to empty the contents of a vessel into the same cratera $\left({ }^{41}\right)$. Many similar depictions of craterae can be found from both eastern and western parts of the Empire (42).

( $\left.{ }^{38}\right)$ Waltzing, op. cit. (note 19), I, 229-230.

(39j CIL VI $327=/$ i i’ 3446.

H ILS 4315b (dated to A.D. 191).

(41) CIMRM 798 and figure 217.

(42) For example, from the Mithiaeum on the Aventine, Rome: CIMRM 481,5 \& 482,2 (with figs. 137 \& 138); Rome: 530; Ostia: 288,2, 299,2, 314 (with fig. 86) \& 291; Volsinii: 659,1; Angera: 719; Interanum (Gaul): 942; Augusta Treverorum: 988; Durnomagus (Germany): 1014; Taunum, Friedberg: 1061 (with fig. 269); Heddernheim: 1083A; Riickingen: 1137A; Dieburg: 1247A (with fig. 323); Mannheim: 1275; Neuenheim: 1283; Karlsruhe: 1292; Fellbach: 1306;? Petronell (Pannonia): 1683; Konjic (Dalmatia): 1896, 4b; Alba Iulia (Dacia): 1935, 1958, 1972, 1974; Sarmizegetusa 
Even through it was a common cultic tool in the worship of Mithras, this would be the only epigraphic attestation of a cratera in a Mithraic context from any part of the Empire, if the inscription is taken to provide evidence for a cult of Mithras. However, a cratera was such a common item in so many cults and also in manifold secular contexts that it is doubtful whether it can be profitably used as a criterion for evaluating the Mithraic significance of this inscription.

The surface of the stone has suffered most in the middle of lines 5 and 6, leading to problems of interpretation especially in line 5. A $\mathrm{T}$ is certainly visible immediately after cratera and an upright as part, or whole, of the second letter. Strangely editors have been unwilling to read an $\mathrm{T}$ here, but have preferred to see it as just part of the letter. Bellido read an $\mathrm{V}$ and suggested tripodem, an interpretation favoured by Alarcão (43), which fits neatly with the cratera. However, not only is there no trace of the bowl of an $\mathrm{V}$ as it joins the upright, but also in a position for the third, or, more likely, the fourth letter, a left-right diagonal can be seen to join a right-left diagonal, suggesting either an 'm' or, more convincingly, a ' $v \backslash$ This would seem then to exclude Bellido's reading. The suggested tripod would not necessarily strengthen the case for a Mithraic context, since a tripod is not commonly found in the iconography of the Mithraic cult.

Lambrino, followed by Yermaseren, suggested that a name stood in the gap as the subject of the verb donavit. This, however, introduces unnecessary, and unresolvable, problems over the grammatical structure, forcing Lambrino to argue that cratera is a Greek accusative. He does not satisfactorily resolve the problem then left with cumt or oumt. It is more straightforward to see Messius Artemidorus as the subject of the verb, leaving the disputed word in the middle of line 5 as the object.

It is difficult to suggest what this word might have been with any certainty, but my suggested reading of titulum has a number

(Dacia): 2034, 2048, 2060, 2066; unknown provenance in Dacia: 2166; Bessapara (Thrace): 2331,1 (with fig. 647); Sanitovo (Thrace): 2334,2; Oxyrhynchus (Egypt): 103 (with fig. 36).

(43) See note 6. 
of points in its favour. It fits the available space, accords with the traces of letters on the stone and also gives a satisfactory meaning: the magister of the sodalicium has donated and set up the actual plaque commemorating the action of the group. There are a number of epigraphic parallels for such tituli: for example, that of P. Hostilius Philadelphus from Philippi put up after his aedileship $\left.{ }^{44}\right)$.

\section{f) Lines 6-7}

The final two lines preserve the name of the magister of the sodalicium. Most editors concur in suggesting Messius Artemidorus except Lambrino, who, correctly in my view, saw the gap as too long for the generally accepted reading. He, therefore, proposed Messius Iul(ius) Artemidorus. However, Messius is not commonly found as a praenomen and the length of the name is just too long for the gap. The reading Messius M(arci) l(ibertus) Artemidorus would seem to fit the available space more satisfactorily $\left({ }^{45}\right)$.

The name Messius is not particularly common in the Iberian peninsula and a number of attestations concern visiting Roman senatorial legati $\left.{ }^{46}\right)$. It occurs on another inscription from Pax lulia and one from Alandroal, eighty kilometres north-east of Beja, and so there is some possibility that it was a local name. If this is true, it would mean that the magister of the sodalicium had most probably arrived in Pax lulia as a slave and subsequently been manumitted. No Messii are yet attested from the area around Bracara $\left({ }^{47}\right)$.

(44) ILS 5466; for other examples, see $I L S 3862,6811,7915,7919$.

${ }^{(45)}$ I am grateful to Dr. J. cTEncarnação for this suggestion.

${ }^{(46)}$ See figure 3 and key to map with full references. The senatorial Messii are nos. 6, 7, 8, 13 a). P. Arias Vilas, P. Le Roux, A. Tranoy, Inscriptions romaines de la province de Lugo, Paris, 1979, 120 somewhat dubiously claim that Messia is an indigenous name. Cf. the sane remarks of J. d'Encarnação at "Conimbriga», 19, 1980, 195. The name is originally Osean: see $R E \mathrm{XV}$, columns 1242-1244.

${ }^{(47)}$ Although C. Messius Q. Decius Valerianus, governor of Tarraconensis in the mid third century, was involved in the reconstruction of roads and bridges around Bracara: see G. ALFõLdy, Fasti hispanienses, Wiesbaden, 1969, 56-59. 
The title magister was indeed a normal one for the chief officer of a collegium and it was common for freedmen to hold this position $\left.{ }^{48}\right)$. The title is also found in connexion with the cult of Mithras, but the only evidence for this comes from Rome (49). Senatorial magistri also appear in a Mithraic context from the fourth century $\left(^{50}\right)$. These inscriptions date from a period when pagan Roman aristocrats were seeking support for the opposition to Christianity and so allowed Mithras to be integrated within the traditional Roman pantheon (51). This probably means that these inscriptions are untypical of earlier Mithraic practice: it would, therefore, be dangerous to argue that the title magister was current in Mithraic communities in the earlier Empire. Pater was the more normal title for the senior figure in a Mithraic cell: he decided whom to admit to the group and he supervised much of the cultic ritual (52). Pater was certainly the title accorded G. Accius Hedychrus at Emerita in the mid second century in a definitely Mithraic context (53).

Most editors have read D.S.F. after magister in line 7. The stone is much abraded here, but some faint traces of letters do survive, most noticeably a downstroke beneath the ed' of Artemidorus and perhaps also the top of the upper curve of an 's' below the ' $m$ ' of the same word. The supposition is plausible, but other possibilities should not be overlooked. I would raise some doubts as to whether an $\mathrm{T}$ can be read with as much certainty as most editors believe $\left({ }^{54}\right)$. A ' $\mathrm{p}^{*}$ could be read here, giving $d(e) s(u a) p($ ecunia) or $d(e) s($ uo $) p$ (osuit). The former is

(48) See Waltzing, op. cit. (note 19), IV, 341-349 (magistri ou collegia); I, 398 (for freedmen as magistri).

(49) CIL VI $717=$ CIMRM 519; CIL VI $734=$ CIMRM 517; CIL VI $2151=$ CIMRM 521 .

(50) CIL VI 47 = CIMRM 369; CIL VI 1675 = CIMRM 516.

(51) R. L. Gordon, Mithraism and Roman society: social factors in the explanation of religious change in the Roman Empire, «Religion», 2, 1972, 92-121, esp. $103 \mathrm{ff}$.

(52) Ibid., 101.

(53) CIMRM Ilk, 779, 781, 793.

(54) BELLido 1967, 35: «seule lettie sure». 
somewhat tautological with donavit, but such expressions as $d(e)$ s(ua) p(ecunia) d(ono) d(edit) do occur (55).

The abbreviation D.S.P. for $d(e) s($ uo $p$ (osuit) can be paralleled with titulum( $\left.{ }^{56}\right)$ and so I would suggest that this would make better sense than $d($ e) $s($ uo $) f($ ecit $)$ : Messius Artemidorus donated the plaque and actually $\wedge^{\wedge}$ set it up in position. A hedera can be seen after the final letter and given the wide spacing of the first two letters (' $\mathrm{d}$ ' and V), it may be plausible to suggest additional hederae after each of the letters.

\section{CONCLUDING REMARKS}

The preceding discussion of the textual problems of the inscription has raised a number of points that cast doubt on the generally held view that the inscription provides evidence for a cult of Mithras at Pax Iulia. First, the rarity of Mithraic inscriptions from the Iberian peninsula as a whole makes it difficult to accept the attribution with any confidence. Secondly, the invocation 'Deo Invicto' does not necessarily have to refer to Mithras, since other deities were accorded the epithet invictus. Thirdly, the mention of a sodalicium with a magister raises further doubts, since collegiate organizations for the worship of Mithras were rare in the Roman world and this would be the only attested example from the Iberian peninsula. Fourthly, the mention of a cratera, despite its frequent representation in Mithraic iconography, carries little weight in such a discussion, since craterae were such essential items not only for many other cults, but also for secular purposes. Finally, the title of the sodalicium, as preserved in the inscription, does not advertise any particularly religious raison d'etre for the group. If it was formed for the worship of Mithras, one might have expected some hint in its title, since there are many attested examples of collegia whose titles include

(55) ILS 355, 1404, 3786, 5069, 5504, 6910, 6914, 7270, 7868, 7881.

(56j With titulum: ILS $1834=$ CIL VI 8978; other examples of the abbreviation, ILS 2278, 2469, 2793, 3856, 4027, 4419, 9309.

Conimbriga, 23 (1984), 69-86 
some reference to a deity ${ }^{(57)}$. On the other hand, it was also common for essentially secular collegia to have patron deities, under whose tutelage they operated and to whom they occasionally made dedications (58). I would suggest that this is the case here: the sodalicium was formed by a group of immigrant settlers in Pax Iulia for general social purposes and to protect their own interests under the patronage of a deity - possibly Mithras, possibly Sol Invictus $\left({ }^{59}\right)$. Some new suggestions have been made as to their activities as recorded in this inscription. I also hope to have demonstrated that too many factors conspire to cast doubt on the generally held view that this inscription provides evidence for 'une institution mithriaque' at Pax Iulia $\left({ }^{60}\right)$.

( ${ }^{57}$ ) Waltzing, op. cit., (note 19), IV, 180-202 with references. For a collegium dei invicti from Paestum, see M. Mello \& G. Voza, Le inscrizicne di Paestum, Naples, 1968, 8-9, no. 3.

(58) WaLtZing, op. cit. (note 19), I, 485-87.

(59) G. Fа в Rе, Le tissu urbain dans le nord-ouest de la péninsule ibérique, «Latomus», 29, 1970, 314-339, esp. 325; A. Tranoy, op. cit., (note 16), 254.

$\left({ }^{60}\right)$ The phrase is that of BELLIDo 1967, 35. Lambrino goes still further and talks about a Mithraeum.

I should like to express my thanks to Dr. J. d'Encarnação, Michael Crawford, Richard Gordon and Joyce Reynolds for discussing this inscription with me and to Christopher Elvin for help with the development of the photographs, taken by myself on visits to the Museu Regional de Beja in April 1980 and December 1981. My greatest debt is to Professor J. A. Crook for all his unfailing encouragement and advice. Any errors of fact or interpretation are my own responsibility. 
FIGURE 3 - Messii in the Iberian peninsula

Key to map

A. LUSITANIA

1. Pax Iulia a) Messiu[s Arte]midorus

b) Messius (Arq. de Beja, 2,1945, p. 234, no. 61).

2. Terena, Alandroal Messius Sympaeron (AP, III, 1, 1967, pp. 172-3)

3. Olisipo Messius L.f. Gal. Rebilus ( $A E$ 1972, 244)

4. Augusta Emerita

a) Messia T. lib. Maura (unpublished)

b) T. Messius Maurus (unpublished)

B. BAETICA

5. Italica

Messius Genialis (HAEp 572)

6. Hispalis M. Messius M.f. Gal. Rusticus Aemilius Verus Aelius Romulus Priscianus Titus Proculus (CIL II 1175)

7. Callenses? M. Messius Rusticus Aemilius Papus Arrius (El Coronil) Proculus Iulius Celsus (CIL II 1371)

8. Salpensa M. Cutius M.f. Priscus Messius Rusticus Aemilius Papus Arrius Proculus Iulius Celsus (CIL II 1282 \& 1283)

9. Iliturgicola et Ipol cobulcola

10. Corduba

C. Messius Rufinus Patriciensis (CIL II 1637)

Birthplace of C. Messius Rufinus (CIL 11 1637)

11. Arva

Messia Fortunata (CIL II 1079)

C. TARRACONENSIS

12. Lead ingot found off coast at Cabo de Palos

C. Messius L.f. ( $A E A, 39,1966$, pp. 48-50, no. 13)

13. Tarraco

14. Legio VII Gemina

a) Messius Maiianus, curator r.p. Tarraconensis (CIL II 4112)

b) Ero[s Mesjsii (on terra sigillata vase in museum at Tarragona) (CIL II 4970, 175)

15. Moral (Astures) Aurelia Messia (CIL II 2582)

$\mathrm{T}$... Messia (CIL II 2624) 


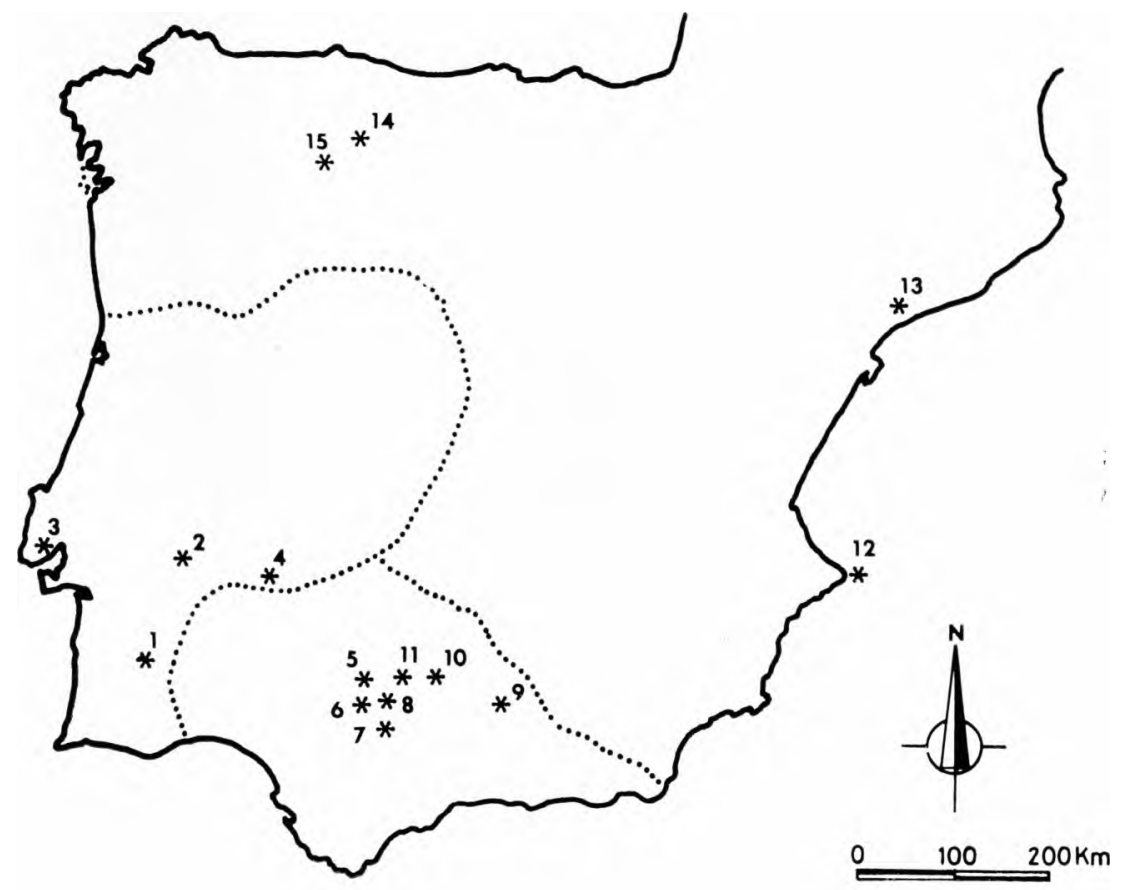

FIG. 3. Messii in the Iberian Peninsula 

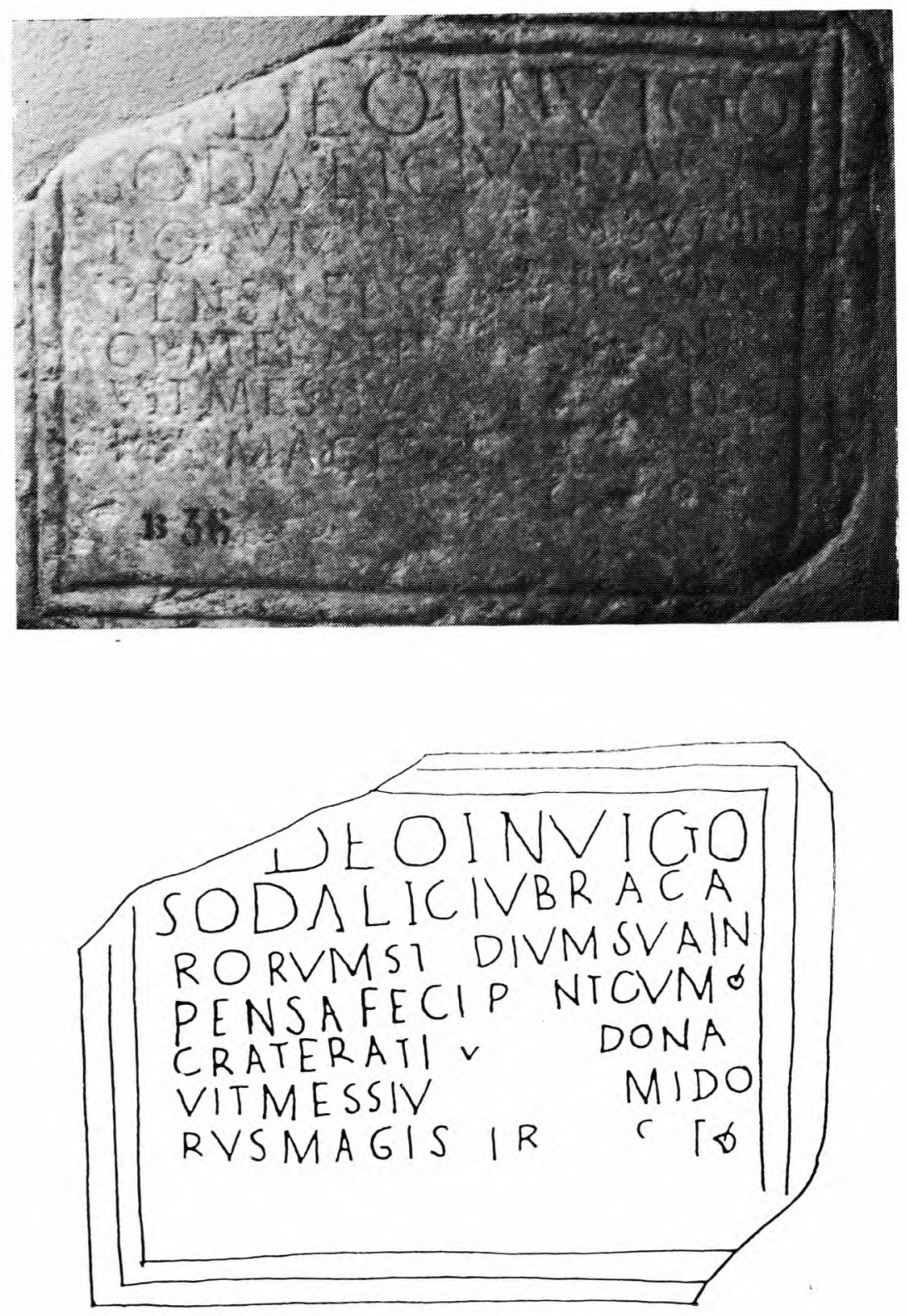